\title{
Die rol van coping in die verband tussen geestelike welstand en depressie by predikante
}

\begin{abstract}
Authors:
Philé Swanepoel ${ }^{1}$

Karel G.F. Esterhuyse ${ }^{1}$

Roelf Beukes ${ }^{1}$

Nico Nortjé ${ }^{1}$

Affiliations:

${ }^{1}$ Department of Psychology, University of the Free State,

South Africa

\section{Correspondence to:}

Karel Esterhuyse

Email:

esterkg@ufs.ac.za

Postal address:

PO Box 39, Bloemfontein

9300, South Africa

Dates:

Received: 03 May 2011

Accepted: 08 Dec. 2011

Published: 01 June 2012

How to cite this article: Swanepoel, P., Esterhuyse, K.G.F., Beukes, R. \& Nortje, N., 2012, 'Die rol van coping in die verband tussen geestelike welstand en depressie by predikante', HTS Teologiese Studies/ Theological Studies 68(1), Art. \#1071, 9 pages. http:// dx.doi.org/10.4102/hts v68i1.1071
\end{abstract}

C 2012. The Authors. Licensee: AOSIS OpenJournals. This work is licensed under the Creative Commons Attribution License.
The role of coping in the relationship between spiritual wellbeing and depression amongst ministers. The aim of this study was to determine the role of coping in the relationship between spiritual well-being and depression among ministers. The research group consisted of 53 Dutch Reformed ministers, all serving in the Northern Cape. Coping was measured by means of the Coping Orientation to Problems Experienced Questionnaire (Carver, Scheier \& Weintraub 1989), spiritual well-being by means of the Spiritual Well-being Questionnaire (Gomez \& Fisher 2003:1977), and depression by means of the Beck Depression Inventory-II (Beck, Steer \& Brown 1996:1-2). The results of this study indicated that problem-focused coping and emotion-focused coping showed no direct relationship with depression. Problemfocused coping also plays no significant role in the relationship between spiritual well-being and depression. Emotion-focused coping, however, plays a role in the relationship between environment-related spiritual well-being and depression. Significant negative relationships between spiritual well-being and depression were found. A significant positive relationship was found between dysfunctional coping and depression. Dysfunctional coping was identified as a mediator in the relationship between personal spiritual well-being and depression. The results of this study are supported by the literature.

\section{Inleiding}

Predikante se beroep as hulpverleners behels 'n unieke stel uitdagings, verantwoordelikhede en stressors (Buys \& Rothmann 2009:127, 128, 134; Redelinghuys \& Rothmann 2005:466-467). Hulle bevind hulle in ' $n$ uiters veeleisende beroep waarin hulle die rol van pastorale versorger, geroepene, berader, administrateur en organiseerder moet vervul (Buys \& Rothmann 2009:127; Redelinghuys \& Rothmann 2005:466-467; Meek et al. 2003:339,342-343). Evers en Tomic (2003:337) is van mening dat sommige predikante nie die eise wat aan hulle gestel word kan vervul nie en gevolglik gevoelens van mislukking ervaar.

Die voorkoms van depressie is ' $\mathrm{n}$ groeiende bron van kommer binne die geestesgesondheidsgemeenskap en word as een van die algemeenste geestesgesondheidsversteurings beskou (Gotlib \& Hammen 2009:1; Westgate 1996:26). Hoewel navorsing hoofsaaklik fokus op stres en uitbranding onder predikante (Breytenbach 2004:31-37; Buys \& Rothmann 2010:1; Evers \& Tomic 2003:329; Grobbelaar 2007:6; Redelinghuys \& Rothmann 2005:466) is daar onder terapeute en navorsers ' $n$ hernude belangstelling in die geestelike aspekte van depressie, gegewe die invloed daarvan op gesondheid en genesing (Rajakumar et al. 2008:90; Westgate 1996:26).

Buys en Rothman (2010:6-7) argumenteer dat daar 'n positiewe verband bestaan tussen uitputting, werkstempo, werksdruk en emosionele eise, met uitputting as 'n aanduier van depressie. Navorsing dui daarop dat 'n aantal predikante hulle werksomstandighede, opleiding en welstand as negatief ervaar, wat tot professionele ontevredenheid lei (Buys \& Rothmann 2009:2; Redelinghuys \& Rothmann 2005:466). Die belangrike invloed wat werkstevredenheid op werknemers se welstand uitoefen, word deur Buys en Rothmann $(2009: 129,135)$ bevestig.

Daar bestaan 'n hoë korrelasie tussen die impak van beroepservaringe en 'n persoon se waardesisteem en coping-strategieë (Moos \& Schaefer 1993:234). Slegs 'n beperkte aantal studies oor predikante se coping-strategieë (Meek et al. 2003:339) en ander aspekte wat verband hou met hulle algehele welstand en geestesgesondheid is beskikbaar wat as raamwerk kan dien waarbinne daar verder oor hierdie tema gereflekteer kan word. Bogenoemde oorsigtelike uiteensetting maak dit duidelik dat daar 'n behoefte bestaan aan verdere navorsing met betrekking tot die verband tussen geestelike welstand en depressie by predikante. Die doel van hierdie artikel is om dié saak verder te ondersoek.

Hierdie teoretiese aanname is nog nie empiries in die Suid-Afrikaanse konteks by predikante bevestig nie, wat aanleiding gee tot die rasionaal en doelstelling van hierdie studie, naamlik 
om die vraag te beantwoord: Wat is die rol van coping met betrekking tot die verband tussen geestelike welstand en depressie by predikante?

\section{Coping}

Daar bestaan verskillende omskrywings vir die konsep coping, maar vir die doel van hierdie studie word dit omskryf as 'veranderde kognitiewe, perseptuele en gedragspogings wat daarop gerig is om interne of eksterne eise te hanteer wat as uitdagend of moeilik beskou kan word' (Herbst, Coetzee \& Visser 2007:58; Lazarus \& Folkman 1984:141; Rothmann \& Van Rensburg 2002:41). Coping verwys dus na bewuste, vrywillige pogings om die omgewing en reaksies op die omgewing onder moeilike omstandighede te reguleer en is gevolglik ' $n$ transaksionele proses tussen die individu en sy of haar omgewing, met die klem op proses (Connor-Smith \& Flachsbart 2007:1080; Herbst et al. 2007:58). Dit is belangrik om te verstaan dat coping nie ' $n$ eendimensionele verskynsel is nie, maar ' $n$ komplekse en dinamiese proses wat die individu, die omgewing en die verhouding tussen die twee beïnvloed (Folkman \& Moskowitz 2004:748). Dit fokus dus op strategieë sowel as resultate.

As strategie verwys coping na die verskillende metodes wat ' $n$ individu toepas om omstandighede te hanteer en as resultaat na die uitkomste van die strategie vir die individu (Rothmann \& Van Rensburg 2002:41). Aan die hand van hierdie beskrywing word nie-coping dus beskou as 'n mislukte poging om te cope, wat deur 'n verskeidenheid van fisiese en psigososiale versteurings gekenmerk word en tot hoër vlakke van stres, depressie en angs aanleiding gee (Carver, Scheier \& Weintraub 1989:267; Meyer, Rothmann \& Pienaar 2003:884; Rothmann \& Van Rensburg 2002:41). Doeltreffende coping-strategieë kan individue dus teen stres beskerm (Meyer et al. 2003:884).

Navorsing dui daarop dat sekere coping-strategieë meer effektief is en beter uitkomste toon as ander. Probleemgebaseerde coping (daarop gerig om die oorsaak van stres te beheer of om die probleem op te los) word as meer doeltreffend beskou, aangesien dit simptome van stres, angs en depressie verminder en beter fisiese en verstandelike gesondheid tot gevolg het (Connor-Smith \& Flachsbart 2007:1081; Fortes-Ferreira et al. 2006:293; Van Berkel 2009:6). Hoewel emosioneelgebaseerde coping (poging om negatiewe emosies wat met 'n situasie geassosieer word te verminder) dikwels swakker uitkomste met betrekking tot fisiese en verstandelike gesondheid toon (Connor-Smith \& Flachsbart 2007:1081), is navorsers oor die algemeen van mening dat emosioneelgebaseerde coping 'n aantal strategieë behels wat beide suksesvol en onsuksesvol is (Connor-Smith \& Flachsbart 2007:1081; Fortes-Ferreira et al. 2006:293; Folkman \& Moskowitz 2004:761; Van Berkel 2009:9). Coping-strategieë wat fokus op negatiewe emosies en gedagtes dra by tot 'n afname in sielkundige welstand, maar coping-strategieë wat daarop gerig is om emosies te reguleer en die toepaslike uitdrukking daarvan uit te bou, dra by tot ' $\mathrm{n}$ toename in sielkundige welstand (Connor-Smith \& Flachsbart 2007:1081; Van Berkel 2009:9).
Individue is geneig om beide probleemgebaseerde coping en emosioneelgebaseerde coping aan te wend om moeilike situasies te hanteer (Carver et al. 1989:267; Herbst et al. 2007:58). Verskillende kombinasies van verskillende strategieë kan coping meer doeltreffend maak en word beskou as buigsame coping. Fortes-Ferreira et al. (2006:294) asook Herbst et al. (2007:58) is van oortuiging dat die gebruik van meerdere strategieë meer effektief is as die gebruik van slegs een strategie, aangesien dit die regulering van emosies en die hantering van die stressor toelaat. Herbst et al. (2007:58) verduidelik verder dat dit belangrik is om die toepaslike probleem- en emosioneelgebaseerde copingvaardighede te kombineer om sodoende suksesvolle coping te verseker. Die navorsers is van mening dat ' $n$ kombinasie van probleemgebaseerde coping en emosioneelgebaseerde coping aangewend moet word om moeilike sitausies te hanteer.

\section{Geestelike welstand}

Holistiese benaderings tot geestesgesondheid, waarin die mens beskou word as 'n eenheid met biologiese, psigologiese, sosiale en geestelike dimensies, en waarin die komponente as interverwant beskou word, neem toe in die psigologie (Westgate 1996:26). Binne hierdie raamwerk word geestelike funksionering gelykwaardig aan fisiese, rasionele of kognitiewe en emosionele funksionering beskou. Geestesgesondheid kan nie eendimensioneel benader word sonder om die balans en interaksie tussen die ander komponente in ag te neem nie (Westgate 1996:26).

Die konsep geestelike welstand is van die mediese welstandsmodel afkomstig en kan beskryf word as die 'integrasie van verskeie dimensies van menslike funksionering, insluitend die sosiale, emosionele, fisiese en geestelike dimensies' (Fisher 1998:29-30, 191; Hodges 2002:110). Geestelike welstand word as 'n breër konsep as godsdiens beskou en word dikwels as ' $n$ persoonlike verhouding met 'n hoër mag of die transendente beskryf, sonder om aan 'n georganiseerde godsdiens gekoppel te word (Gomez \& Fisher 2005:1108; Sorajjakool et al. 2008:522).

Hoewel dit uit die literatuur blyk dat die omskrywing van geestelike welstand problematies is, is dit duidelik dat daar algemene temas binne die verskillende beskouings oor geestelike welstand voorkom. Hierdie temas is 'n verhouding met God of 'n hoër mag of skepper van die heelal of kosmos; 'n verbintenis of verhouding met die gemeenskap, self en omgewing; betekenis en doel in die lewe; 'n intrinsieke waardesisteem; subjektiewe ervarings (Chiu et al. 2004:409; Fisher, Francis \& Johnson 2000:134-135; Gomez \& Fisher 2003:1975-1976; Gomez \& Fisher 2005:1108; Hyman \& Handal 2006:278; Rajakumar et al. 2008:91; Sarajjakool et al. 2008:522; Westgate 1996:27-31).

Vir die doeleindes van hierdie studie sal die multidimensionele model van geestelike welstand soos voorgestel deur Fisher (1998:193), en die geestelike welstandvraelys, soos ontwikkel deur Gomez en Fisher (2003:1977) as 
teoretiese raamwerk gebruik word. Volgens die multidimensionele model behels geestelike welstand vier faktore, naamlik die persoonlike, die gemeenskap, die omgewing en die transendente (Fisher 1998:191).

Gomez en Fisher (2003) beskryf geestelike welstand soos volg:

Spiritual well-being can be defined in terms of a state of being reflecting positive feelings, behaviours, and cognitions of relationships with oneself, others, the transcendent and nature, that in turn provide the individual with a sense of identity, wholeness, satisfaction, joy, contentment, beauty, love, respect, positive attitudes, inner peace and harmony, and purpose and direction in life. (p. 1976)

Geestelike welstand kan dus kortliks gedefinieer word as die mate waarin mense in harmonie leef binne verhoudings met hulself(intrapersoonlik), ander(gemeenskapofinterpersoonlik), die natuur (omgewing) en God (transendente) (Chiu et al. 2004:411-412; Fisher 1998:191; Gomez \& Fisher 2003:1976). Die vier domeine van geestelike welstand is interverwant van aard en gesamentlik dui hulle op die totale geestelike welstand van 'n persoon (Fisher et al. 2000:135; Gomez \& Fisher 2003:1976).

\section{Depressie}

Depressie word sedert die derde uitgawe van die Diagnostic and Statistical Manual of Mental Disorders (DSM) onder die kategorie gemoedsversteurings geklassifiseer (Barlow \& Durand 2009:208; Dubovsky \& Dubovsky 2002:4). Gemoed word beskryf as 'n deurdringende en volgehoue emosionele oriëntasie wat intern ervaar word en wat ' $n$ individu se gedrag en persepsie van die wêreld beïnvloed (Dubovsky \& Dubovsky 2002:4; Sadock \& Sadock 2007:527).

Gemoedsversteurings is gevolglik'n groep kliniese toestande wat gekenmerk word deur 'n gevoel van verlies aan beheer en subjektiewe ervaringe van uitermatige angs (Sadock \& Sadock 2007:527), waar die oorheersende simptoom 'n blywende verandering van gemoed is (Carr 2001:84; Sadock \& Sadock 2007:527; Serretti 2005:36; Stevens \& Rodin 2007:20). Aangesien die oorheersende simptoom 'n verandering in gemoed is, het dit gebruiklik geword om die toestand as 'n primêre gemoedsversteuring te beskryf (Beck \& Alford 2009:8). Die versteuring word egter met ' $n$ aantal ander tekens en simptome geassosieer wat nie net die affektiewe insluit nie, maar ook kognitiewe, fisiese en sosiale aspekte (Barlow \& Durand 2009:208; Beck \& Alford 2009:8; Carr 2001:83; Sadock \& Sadock 2007:527).

Depressie word onderskei van normale emosies soos hartseer of droefheid as meer intens en aanhoudend en moet vir ten minste twee weke aanwesig wees (Sadock \& Sadock 2007:543; Stevens \& Rodin 2007:20). Depressie beïnvloed ook ander aspekte van ' $n$ individu se lewe negatief, soos byvoorbeeld die persoon se interpersoonlike verhoudings, werksverrigting en bevrediging deur vryetydsaktiwiteite (Carr 2001:84; Sadock \& Sadock 2007:527, 543). Sommige outeurs (Beck et al. 1979:3; Beck 2002:31; Clark, Beck \&
Alford 1999:51) is van oortuiging dat depressie 'n kognitiewe toestand is. Die kognitiewe teorie van depressie word gebaseer op 'n inligtingsverwerkingsmodel (Beck 2002:29; Clark et al. 1999:77) waar individue wat wanaangepaste kognitiewe patrone het meer geneig is om gebruik te maak van negatiewe inligtingsverwerking oor hulleself, hulle ervaringe en hulle toekoms (McGinn 2000:257; McIntosh \& Fischer 2000:153). Hulle sien hulleself as waardeloos, onbevoeg, siek of veronreg, ag hulle ervarings as negatief en hulle sien hul toekoms as hopeloos, met aanhoudende ontbering en frustrasie (Beck et al. 1979:11; Beck 1970:21-23; McGinn 2000:257; McIntosh \& Fischer 2000:153). Die samevoeging van negatiewe sienings staan bekend as die kognitiewe triade van depressie (McGinn 2000:257; McIntosh \& Fischer 2000:153).

Kognitiewe foute wat tydens periodes van depressie begaan word, is: (1) willekeurige gevolgtrekking ('n gevolgtrekking word gemaak in die afwesigheid van ondersteunende bewyse vir die gevolgtrekking), (2) selektiewe onttrekking (daar word op spesifieke besonderhede buite konteks gefokus), (3) oorveralgemening ('n gevolgtrekking word gemaak op grond van een of twee geïsoleerde insidente), (4) vergroting en verkleining (oor- of onderbeklemtoning van die betekenis van 'n gebeurtenis), (5) verpersoonliking (die individu se neiging om eksterne gebeure met homself te verbind) en, (6) tweedelige denke (die neiging om ervaringe in een van twee teenoorgestelde kategorieë te plaas) (Clark et al. 1999:103; Henriques \& Leitenberg 2002:246).

\section{Predikante}

Internasionale studies toon dat predikante in Nederland binne die eerste vyftien jaar hulle beroep en masse verlaat terwyl $53 \%$ van predikante in Australië weens 'n hoë mate van druk oorweeg om die bediening te verlaat en $38 \%$ die kompleksiteit van die bediening en die eise van pastorale versorging as oorweldigend ervaar (Cooke 2007:10). In die Suid-Afrikaanse konteks toon navorsing deur Breytenbach (2004:12) dat 290 predikante in die Nederduitse Gereformeerde (NG) kerk die bediening tussen 1987 en 1997 verlaat het. Nel (2004:586) meld dat ' $n$ geraamde 33\% van alle predikante dit oorweeg, al oorweeg het, of reeds die bediening verlaat het. Cooke (2007:10) wys daarop dat die mediese skema vir die NG kerk in Suid-Afrika in die eerste helfte van 2002 R1 168000 aan die verskaffing van antidepressante aan predikante bestee het (gemiddeld 3816 voorskrifte).

Bogenoemde statistiek en navorsingsresultate dui daarop dat 'n groot groep predikante lae werkstevredenheid ervaar en volgens die literatuur (Breytenbach 2004:3; Buys \& Rothmann 2009:127-128; Cooke 2007:11; Evers \& Tomic 2003:331; Grobbelaar 2007:4-5; Redelinghuys \& Rothmann 2005:466) kan die volgende twee sake as van die belangrikste oorsake daarvoor aangedui word.

\section{Werksomstandighede}

Predikante ervaar druk as gevolg van hul werksomstandighede en werksverwante stressors soos werksoorlading, tydsdruk, 
lang werksure, rolkonflik en rolonduidelikheid, tesame met hulle veeldoelige rol as predikant, administrateur, bestuurder, geestelike versorger, eggenoot en ouer. Die werksomstandighede het 'n groot invloed op predikante se emosionele gesondheid (Breytenbach 2004:3, 37; Buys \& Rothmann 2009:127-128; Redelinghuys \& Rothmann 2005:466), gegewe dat hulle geneig is om hulle eie behoeftes ondergeskik te stel aan dié van die gemeentelede (Breytenbach 2004:59; Buys \& Rothmann 2009:128, 134; Grobbelaar 2007:4-5). Daarbenewens hanteer predikante daagliks lidmate se verhoudingsprobleme, siektes, lyding en dood, persoonlike probleme, geestelike konflik en emosionele probleme wat 'n wesenlike bydrae tot stres in die lewe van predikante lewer (Cooke 2007:10-12, 17; Evers \& Tomic 2003:331).

\section{Die veranderde rol van die kerk in die samelewing}

Verdere druk wat op predikante geplaas word, hou verband met die veranderde rol van die kerk in die samelewing te wyte aan die sosiale en politieke veranderinge in Suid-Afrika sedert 1994 (Buys \& Rothmann 2009:127; Cooke 2007:11). Predikante het toenemend te doen met multikulturele gemeentes en moet die kerk lei binne 'n liberale demokrasie (Buys \& Rothmann 2009:127). Dit is nie net die beroep van die predikant wat onder druk is nie, maar die persoon self is ook oorlaai en volgens Breytenbach (2004:37) en Nel $(2004: 586,588)$ is die openbare rol van die predikant uitgedien. Strukturele veranderinge binne die kerk-kulturele omgewing veroorsaak ook dat die onderlinge ondersteuning in die gemeente verminder en daar word dikwels van die predikant verwag om die hoofbron van ondersteuning te wees (Grobbelaar 2007:5). Hierdie aspekte van 'n predikant se beroep kan volgens Evers en Tomic (2003:331) emosioneel uitputtend wees.

\section{Coping, geestelike welstand en depressie}

Doeltreffende coping-meganismes is van belang om individue in staat te stel om beheer oor hulle lewe en emosies te herwin en te behou. Beheer is 'n basiese psigologiese behoefte en met behulp van effektiewe coping-meganismes kan mense die kwaliteit van hul verhoudingslewe (met self, gemeenskap, natuur en opperwese) verbeter of herstel. Hierdie psigologiese belewenis is die basis van 'n geestelike lewe. Die teenoorgestelde aanname kan ook gemaak word, naamlik dat 'n gebrek aan coping-meganismes 'n gebrek aan beheer veroorsaak, wat 'n depressiewe gemoedstoestand tot gevolg kan hê. Coping vorm dus 'n basiese onderbou vir geestelike welstand en is ' $n$ belangrike veranderlike met betrekking tot die verband tussen geestelike welstand en depressie.

\section{Metode van ondersoek}

Uit 'n groep van ongeveer 80 NG-kerk predikante, waarvan almal in die Noord-Kaap werksaam is, is $53(66 \%)$ by wyse van 'n nie-waarskynlikheidsteekproefmetode by die studie betrek. Die meerderheid (94.3\%) is getroud en is hoofsaaklik
$(77.4 \%)$ in plattelandse gemeentes werksaam. Deelnemers is versoek om 'n biografiese vraelys, die Cope-vraelys (Carver et al. 1989:267), die Geestelike Welstandsvraelys (Gomez \& Fisher 2003:1977) en die Beck-depressievraelys II (Beck et al. 1996) te voltooi.

Die Cope-vraelys verskaf inligting rakende probleemgebaseerde coping, emosioneelgebaseerde coping en disfunksionele coping. In 'n studie uitgevoer onder voorgraadse studente, rapporteer Carver et al. (1989:273) Cronbach alfa-koëffisiënte wat tussen 0.45 en 0.92 varieer. Die Geestelike Welstandsvraelys lewer vier skale wat die vier domeine (persoonlike, gemeenskapsverwante, omgewingsverwante en transendente welstand) van geestelike welstand verteenwoordig met ' $n$ Cronbach alfakoëffisiënte wat tussen 0.82 en 0.95 vir die vier domeine wissel (Gomez \& Fisher 2003:1984). Bevredigende bewyse vir die Geestelike Welstandsvraelys se interne konsekwentheid, asook konstruk-, diskriminante, voorspellings- en saamvallende geldigheid is deur Gomez en Fisher (2003:1978-1989) in 'n reeks van vier studies gevind. Wat die Beck-depressievraelys betref, is Cronbach alfa-koëffisiënte van 0.92 (Beck, Steer \& Brown 1996) gevind.

In die hiërargiese regressie-ontledings (tegniek waar navorser beheer het oor die invoer en weglaat van voorspellerveranderlikes in die regressiemodel) wat volg, is geestelike welstand (wat vier metings verskaf, naamlik omgewingsverwant, persoonlik, gemeenskapsverwant en transendent), die voorspellerveranderlikes en depressie (van predikante) as kriteriumveranderlikes gebruik. Die rol van coping (wat drie metings verskaf, naamlik probleemgebaseer, emosioneelgebaseer en disfunksioneel) is in hierdie verband vir die predikante ondersoek. Met hierdie prosedure word die regressie-ontledings in drie stappe uitgevoer. In die eerste stap word die ontleding van enkelveranderlikes (net een veranderlike per keer word ingevoer) hanteer: geestelike welstand word tot die regressievergelyking toegevoeg om die unieke bydrae daarvan tot predikante se depressie te ondersoek en, daaropvolgend, word coping in die vergelyking opgeneem om dié veranderlike se unieke bydrae te bepaal. Gedurende stap twee word die daaropvolgende opname van beide voorspellers (geestelike welstand en coping) ondersoek om elk se beduidende proporsionele bydrae tot die voorspelling van die kriteriumveranderlike te bepaal. In die derde stap word die produk tussen geestelike welstand en coping, in die voorspelling van depressie, ondersoek. Om multi-kolonialiteit (hoë korrelasie tussen voorspellerveranderlikes) te voorkom (Howell 2007:5), is eers die afwykingstellings van die veranderlikes bereken, alvorens die produk bereken is.

Met stap een word bepaal of geestelike welstand sowel as coping ' $n$ beduidende direkte verband met predikante se depressie toon. Indien die veranderlikes daaropvolgend tot die vergelyking gevoeg word, kan die volgende afgelei word:

- Indien die geestelike welstandstelling beduidend in stap 2 bly, terwyl die coping-telling onbeduidend word, 
kan afgelei word dat coping 'n mediatorveranderlike (mediatorveranderlike dien as tussenveranderlike tot die mate wat dit die verband tussen die voorspeller- en die kriteriumveranderlike kan verklaar) is.

- Indien die geestelike welstandstelling onbeduidend in stap 2 word, terwyl die coping-telling beduidend bly, dan is dit ' $n$ aanduiding van die verstrengeling (onbekend of dit moderator of mediator is) van veranderlikes (Gravetter \& Wallnau 2000).

- Uit die resultate van die produkterm (stap 3) kan afgelei word of daar ' $n$ beduidende interaksie is, wat dan aanduidend van 'n moderator-effek kan wees ('n Moderatorveranderlike beïnvloed die rigting en/ of sterkte van die verband tussen die voorspeller- en kriteriumveranderlikes) (Anastasi \& Urbania 1997).

Alle ontledings is met behulp van die SPSS-programmatuur uitgevoer (SPSS Incorporated 2009).

\section{Resultate}

Aangesien depressie by predikante ' $n$ belangrike fokuspunt van die studie is, is eerstens die vlak van depressie wat hulle ervaar, ondersoek.Volgens die Beck-depressievraelys kan die volgende indelings gemaak word, naamlik minimale, ligte, matige en ernstige vlakke van depressie. Ongeveer driekwart (40) van die predikante presenteer met minimale vlakke van depressie, terwyl slegs een persoon binne die ernstige kategorie val. Die gemiddelde depressietelling vir die ondersoekgroep is 9.15 (maksimumtelling is 63) met 'n standaardafwyking van 9.42 wat daarop dui dat die predikantegroep nie enigsins ernstige vlakke van depressie ervaar nie.

Voordat tot die hiërargiese regressie-ontledings oorgegaan is, is die korrelasiekoëffisiënte tussen al die betrokke veranderlikes vir die totale groep $(n=53)$ bereken. Op die $1 \%$-peil is beduidende korrelasies tussen depressie en een van die coping-skale, naamlik disfunksionele coping, asook tussen depressie en twee van die geestelike welstandskale (persoonlik en gemeenskap) gevind. Op die 5\%-peil kom ook 'n beduidende verband tussen depressie en die geestelike welstandskaal (transendenteel) voor. Vervolgens is die moontlike rol van coping met betrekking tot die verband tussen geestelike welstand en depressie by predikante ondersoek deur afsonderlike hiërargiese regressie-ontledings vir die vier geestelike welstandskale te doen.

\section{Coping, persoonlike geestelike welstand en depressie}

Die resultate van die drie coping-skale as tussenkomende veranderlikes in die verband tussen persoonlike geestelike welstand en depressie word in Tabel 1 verskaf.

Volgens stap 1 van die resultate is dit duidelik dat persoonlike geestelike welstand op die 1\%-peil 'n beduidende negatiewe verband met depressie by predikante toon. Hieruit word afgelei dat persoonlike geestelike welstand 'n direkte invloed op depressie het en dat respondente met hoë
TABEL 1a: Hiërargiese regressie-ontledings met persoonlike geestelike welstand as onafhanklike veranderlike en probleem coping as tussenkomende veranderlike.

\begin{tabular}{lccc}
\hline Stappe & \multicolumn{3}{c}{ Beta } \\
\cline { 2 - 4 } & Persoonlike (GP) & $\begin{array}{c}\text { Coping } \\
\text { (Probleem) }\end{array}$ & GP x Probleem \\
\hline 1 & $-0.759 * *$ & - & - \\
\hline Alternatief 1 & - & -0.059 & - \\
2 & $-0.769 * *$ & 0.062 & - \\
3 & - & - & -0.167 \\
\hline GP, Geestelike welstand - Persoonlik. & & \\
$* *, p \leq 0.01$ & &
\end{tabular}

$* *, p \leq 0.01$

TABEL 1b: Hiërargiese regressie-ontledings met persoonlike geestelike welstand as onafhanklike veranderlike en emosionele coping as tussenkomende veranderlike. \begin{tabular}{llll}
\hline Stappe & \multicolumn{3}{c}{ Beta } \\
\cline { 2 - 4 } & Persoonlike (GP) & $\begin{array}{c}\text { Coping } \\
\text { (Emosioneel) }\end{array}$ & GP x Emosioneel
\end{tabular}

\begin{tabular}{lccc}
\hline 1 & $-0.759 * *$ & - & - \\
Alternatief 1 & - & -0.066 & - \\
2 & $-0.759 * *$ & -0.005 & - \\
3 & - & - & -0.021 \\
\hline $\begin{array}{l}\text { GP, Geestelike welstand } \\
* *, p \leq 0.01\end{array}$ & &
\end{tabular}

TABEL 1c: Hiërargiese regressie-ontledings met persoonlike geestelike welstand as onafhanklike veranderlike en disfunksionele coping as tussenkomende veranderlike. Stappe

\begin{tabular}{lccc} 
& \multicolumn{3}{c}{ Beta } \\
\cline { 2 - 4 } & Persoonlike (GP) & $\begin{array}{c}\text { Coping } \\
\text { (Disfunksioneel) }\end{array}$ & GP x Disfunksioneel \\
\hline 1 & $-0.759 * *$ & - & - \\
Alternatief & - & $0.382^{* *}$ & - \\
1 & & 0.067 & - \\
2 & $-0.730^{* *}$ & - & -0.076 \\
3 & - & & \\
\hline GP, Geestelike welstand - Persoonlik. & & \\
$* *, p \leq 0.01$ & & &
\end{tabular}

persoonlike geestelike welstandsvlakke geneig is om lae vlakke van depressie te ervaar. Beide probleemgebaseerde en emosioneelgebaseerde coping kon nie as 'n mediator (stap 2) of moderator (onbeduidende produkterm in stap 3) in die verband tussen persoonlike geestelike welstand en depressie by predikante geïdentifiseer word nie.

Disfunksionele coping toon wel op die 1\%-peil 'n beduidende positiewe verband met die vlak van depressie wat predikante ervaar. Hieruit word afgelei dat disfunksionele coping depressie direk beïnvloed en dat respondente met hoë vlakke van disfunksionele coping geneig is om hoë vlakke van depressie te ervaar. Wanneer na die tweede stap se resultate gekyk word, is dit duidelik dat disfunksionele coping se bydrae nie meer beduidend is nie. Aangesien persoonlike geestelike welstand steeds ' $n$ beduidende verband toon, kan in hierdie geval die afleiding gemaak word dat disfunksionele coping 'n mediator in die verband tussen persoonlike geestelike welstand en depressie by predikante is. Gegewe hierdie mediatoreffek, is ' $n$ afsonderlike regressie-ontleding gedoen ten einde die verband tussen disfunksionele coping en persoonlike geestelike welstand te ondersoek. Die resultaat van bogenoemde word grafies in Figuur 1 voorgestel.

Die verband ( $\beta=-0.431$ ) tussen disfunksionele coping en persoonlike geestelike welstand is op die 1\%-peil beduidend. Dit volg dat hoe hoër die predikante se vlak van persoonlike geestelike welstand neig, hoe laer neig hul vlak van disfunksionele coping, wat daartoe lei dat hul laer vlakke van depressie ervaar. 


\section{Coping, gemeenskapsverwante geestelike welstand en depressie}

Die resultate van die drie coping-skale as tussenkomende veranderlikes in die verband tussen gemeenskapsverwante geestelike welstand en depressie word in Tabel 2 getoon.

Eerstens is dit duidelik dat gemeenskapsverwante geestelike welstand op die 1\%-peil 'n beduidende negatiewe verband met depressie by predikante toon. Hieruit word afgelei dat gemeenskapsverwante geestelike welstand 'n direkte invloed op depressie het en dat respondente met hoë gemeenskapsverwante geestelike welstandsvlakke geneig is om lae vlakke van depressie te ervaar. Disfunksionele, probleemgebaseerde en emosioneelgebaseerdecoping kon nieas 'n mediator (stap 2) of moderator (onbeduidende produkterm in stap 3) in die verband tussen gemeenskapsverwante geestelike welstand en depressie by predikante geïdentifiseer word nie.

\section{Coping, omgewingsverwante geestelike welstand en depressie}

Die resultate van die drie coping-skale as tussenkomende veranderlikes in die verband tussen omgewingsverwante geestelike welstand en depressie word in Tabel 3 verskaf.

Eerstens is dit duidelik dat omgewingsverwante geestelike welstand op die 1\%-peil 'n beduidende negatiewe verband met depressie by predikante toon. Hieruit word afgelei dat omgewingsverwante geestelike welstand 'n direkte invloed op depressie het en dat respondente met hoë omgewingsverwante geestelike welstandsvlakke geneig is om lae vlakke van depressie te ervaar. Beide probleemgebaseerde en disfunksionele coping kon nie as 'n mediator (stap 2) of moderator (onbeduidende produkterm in stap 3) in die verband tussen omgewingsverwante geestelike welstand en depressie by predikante geïdentifiseer word nie.

Emosioneelgebaseerde coping is wel as 'n moderator (beduidende produkterm by stap 3) in die verband tussen omgewingsverwante geestelike welstand en depressie by predikante geïdentifiseer. Die aard van hierdie moderatoreffek is ondersoek deur die verband tussen omgewingsverwante geestelike welstand en die kriterium (depressie) vir diegene wat onderskeidelik laag en hoog op die moderatorveranderlike (emosionele coping) is, te bepaal. Vir hierdie doel word twee aparte regressielyne bereken - een vir diegene wat hoog op emosionele coping (op of hoër as die 75ste persentiel, $N=18$ ) presteer het, en een vir diegene wat laag op emosionele coping (op of laer as die 25ste persentiel, $N=13$ ) presteer het. Die regressielyne word in Figuur 2 voorgestel.

Vir predikante met 'n hoë vlak van emosionele coping (boonste 25\%) kom 'n relatief vinnige daling in die regressielyn voor (helling $=-1.144$ ), terwyl vir diegene met lae emosionele coping (onderste 25\%) die daling heelwat kleiner is (helling $=-0.422$ ). Dit dui daarop dat vir diegene met hoë vlakke van emosionele coping daar met 'n toename
TABEL 2a: Hiërargiese regressie-ontledings met gemeenskapsverwante geestelike welstand as onafhanklike veranderlike en probleem coping as tussenkomende veranderlike.

\begin{tabular}{lccc}
\hline Stappe & \multicolumn{3}{c}{ Beta } \\
\cline { 2 - 4 } & Gemeenskap (GG) & $\begin{array}{c}\text { Coping } \\
\text { (Probleem) }\end{array}$ & GG x Probleem \\
\hline 1 & $-0.364^{* *}$ & - & - \\
Alternatief 1 & - & -0.059 & - \\
2 & $-0.375^{* *}$ & 0.041 & - \\
3 & - & - & -0.179 \\
\hline GG, Gestelike welstand - Gemeenskap. & & \\
$* *, p \leq 0.01$ & & &
\end{tabular}

TABEL 2b: Hiërargiese regressie-ontledings met gemeenskapsverwante geestelike welstand as onafhanklike veranderlike en emosionele coping as tussenkomende veranderlike.

\begin{tabular}{lccc}
\hline Stappe & \multicolumn{3}{c}{ Beta } \\
\cline { 2 - 4 } & Gemeenskap (GG) & $\begin{array}{c}\text { Coping } \\
\text { (Emosioneel) }\end{array}$ & GG x Emosioneel \\
\hline 1 & $-0.364^{* *}$ & - & - \\
Alternatief 1 & - & -0.066 & - \\
2 & $-0.361 * *$ & -0.031 & - \\
3 & - & - & -0.119 \\
\hline GG, Gestelike welstand - Gemeenskap. & & \\
$* *, p \leq 0.01$ & & &
\end{tabular}

TABEL 2c: Hiërargiese regressie-ontledings met gemeenskapsverwante geestelike welstand as onafhanklike veranderlike en disfunksionele coping as tussenkomende veranderlike.

\begin{tabular}{lccc}
\hline Stappe & \multicolumn{3}{c}{ Beta } \\
\cline { 2 - 4 } & Gemeenskap (GG) & $\begin{array}{c}\text { Coping } \\
\text { (Disfunksioneel) }\end{array}$ & GG x Disfunksioneel \\
\hline 1 & $-0.364^{* *}$ & - & - \\
Alternatief 1 & - & $0.382^{* *}$ & - \\
2 & $-0.283^{* *}$ & $0.307^{*}$ & - \\
3 & - & - & -0.181 \\
\hline GG, Gestelike welstand - Gemeenskap. & & \\
$*, p \leq 0.05 ; * *, p \leq 0.01$ & & &
\end{tabular}

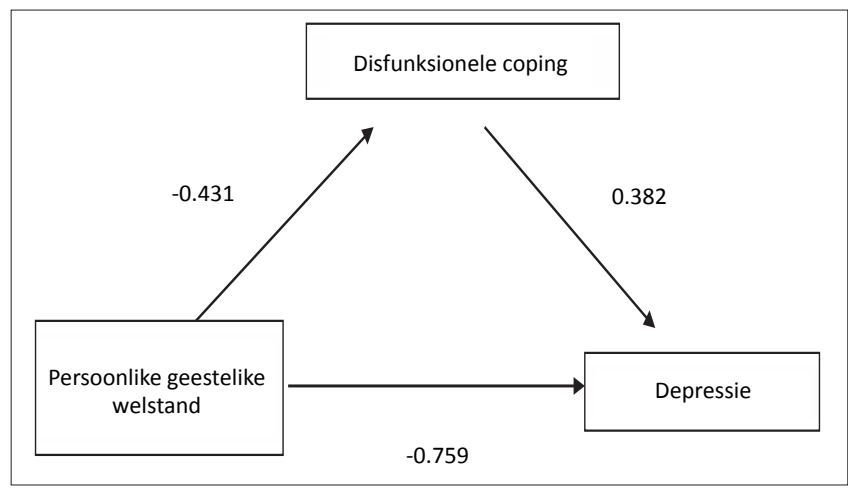

FIGUUR 1: Tweede stap van regressie-ontleding om mediatoreffek van disfunksionele coping in die verband tussen persoonlike geestelike welstand en depressie by predikante te illustreer.

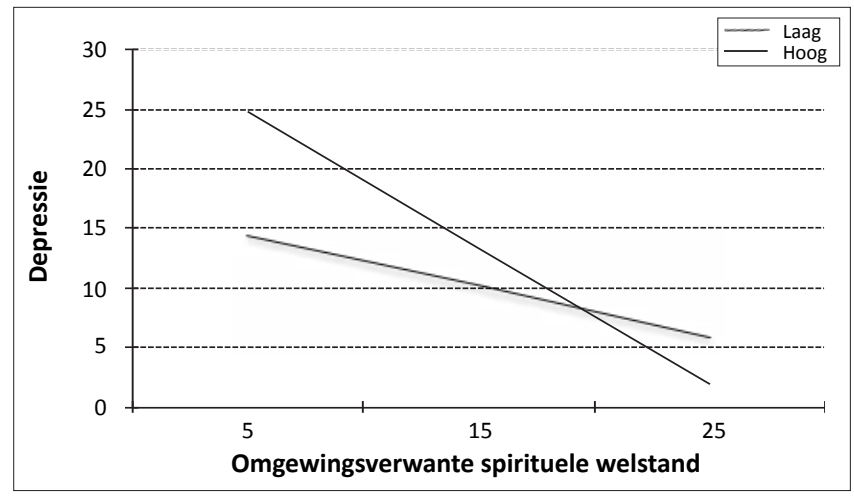

FIGUUR 2: Regressielyne van lae en hoë emosionele coping met omgewingsverwante geestelike welstand as voorspeller van depressie by predikante. 
in omgewingsverwante geestelike welstand 'n redelik vinnige afname in depressie voorkom, terwyl by diegene met lae vlakke van emosionele coping die afname in depressie, met die toename in omgewingsverwante geestelike welstand, nie so groot is nie. Dit blyk verder dat wanneer beide groepe (laag en hoog op emosionele coping) lae vlakke van omgewingsverwante geestelike welstand ervaar, diegene met hoë emosionele coping heelwat hoër vlakke van depressie ervaar as diegene met lae emosionele coping.

\section{Coping, transendente geestelike welstand en depressie}

Die resultate van die drie coping-skale as tussenkomende veranderlikes in die verband tussen transendente geestelike welstand en depressie word in Tabel 4 verskaf.

Transendente geestelike welstand toon wel op die 1\%-peil 'n beduidende negatiewe verband met depressie by predikante. Hieruit word afgelei dat transendente geestelike welstand 'n direkte invloed op depressie het en dat respondente met hoë transendente geestelike welstandsvlakke geneig is om lae vlakke van depressie te ervaar. Disfunksionele, probleemgebaseerde en emosioneelgebaseerde coping kon nie as 'n mediator (stap 2) of moderator (onbeduidende produkterm in stap 3) in die verband tussen transendente geestelike welstand en depressie by predikante geïdentifiseer word nie.

\section{Bevindings en aanbevelings}

Op grond van bestaande navorsing (Breytenbach 2004:12) sou 'n groter voorkoms van depressie by die predikante wat by die steekproef betrek is verwag kon word, veral aangesien hulle gemiddeld reeds 20 jaar in die bediening is. Tog toon $75 \%$ van die betrokke groep minimale vlakke van depressie. Een persoon het 'n ernstige vlak van depressie ervaar terwyl ses persone matige vlakke van depressie ervaar het. Hierdie bevinding kom voor ten spyte van die druk wat predikante in hulle beroep ervaar en die impak daarvan op hulle emosionele welstand (Breytenbach 2004:31-37; Buys \& Rothmann 2009:2; Evers \& Tomic 2003:329; Redelinghuys \& Rothmann 2005:466). Die literatuur meld dat SuidAfrikaanse predikante tog geleer het om met stressors te cope (Breytenbach 2004:20; Grobbelaar 2007:116-117), en die strategieë kan moontlik binne die raamwerk van die kognitiewe teorie van depressie as beskermende faktor teen depressie beskou word.

Tweedens is bevind dat beduidende korrelasies tussen depressie en drie geestelike welstandskale (persoonlik, gemeenskap en transendenteel) voorkom. Al drie hierdie verbande is negatief, wat daarop dui dat hoe hoër predikante se persoonlike, gemeenskapsverwante en/of transendente geestelike welstand is, hoe laer hulle vlakke van depressie geneig is om te wees. 'n Beduidende positiewe verband tussen disfunksionele coping en depressie is verder ook geïdentifiseer. Hierdie positiewe verband dui daarop dat hoe hoër die persone se vlakke van disfunksionele coping
TABEL 3a: Hiërargiese regressie-ontledings met omgewingsverwante geestelike welstand as onafhanklike veranderlike en probleem coping as tussenkomende veranderlike.

\begin{tabular}{lccc}
\hline Stappe & \multicolumn{3}{c}{ Beta } \\
\cline { 2 - 4 } & Omgewing (GO) & $\begin{array}{c}\text { Coping } \\
\text { (Probleem) }\end{array}$ & GO x Probleem \\
\hline 1 & -0.223 & - & - \\
Alternatief 1 & - & -0.059 & - \\
2 & -0.243 & 0.047 & - \\
3 & - & - & -0.106 \\
\hline GO, Geestelike welstand - Omgewing. & &
\end{tabular}

TABEL 3b: Hiërargiese regressie-ontledings met omgewingsverwante geestelike welstand as onafhanklike veranderlike en emosionele coping as tussenkomende veranderlike.

\begin{tabular}{lccc}
\hline Stappe & \multicolumn{3}{c}{ Beta } \\
\cline { 2 - 4 } & Omgewing (GO) & $\begin{array}{c}\text { Coping } \\
\text { (Emosioneel) }\end{array}$ & GO x Emosioneel \\
\hline 1 & -0.223 & - & - \\
Alternatief 1 & - & -0.066 & - \\
2 & -0.222 & -0.004 & - \\
3 & - & - & $-0.278^{*}$ \\
\hline GO, Geestelike welstand - Omgewing. & & \\
$*, p \leq 0.05$ & & &
\end{tabular}

TABEL 3c: Hiërargiese regressie-ontledings met omgewingsverwante geestelike welstand as onafhanklike veranderlike en disfunksionele coping as tussenkomende veranderlike.

\begin{tabular}{lccc}
\hline Stappe & \multicolumn{3}{c}{ Beta } \\
\cline { 2 - 4 } & Omgewing (GO) & $\begin{array}{c}\text { Coping } \\
\text { (Disfunksioneel) }\end{array}$ & GO x Disfunksioneel \\
\hline 1 & -0.223 & - & - \\
Alternatief 1 & - & $0.382^{* *}$ & - \\
2 & -0.140 & $0.349^{*}$ & - \\
3 & - & - & 0.037 \\
\hline GO, Geestelike welstand - Omgewing. & & \\
$*, p \leq 0.05 ; * *, p \leq 0.01$ & & &
\end{tabular}

TABEL 4a: Hiërargiese regressie-ontledings met transendente geestelike welstand as onafhanklike veranderlike en probleem coping as tussenkomende veranderlike.

\begin{tabular}{lccc}
\hline Stappe & \multicolumn{3}{c}{ Beta } \\
\cline { 2 - 4 } & Transendent (GT) & $\begin{array}{c}\text { Coping } \\
\text { (Probleem) }\end{array}$ & GT x Probleem \\
\hline 1 & $-0.325^{*}$ & - & - \\
Alternatief 1 & - & -0.059 & - \\
2 & $-0.769 * *$ & 0.062 & - \\
3 & - & - & -0.167 \\
\hline GT, Geestelike welstand - Transendent. & & \\
$*, p \leq 0.05 ; * *, p \leq 0.01$ & &
\end{tabular}

$*, p \leq 0.05 ; * *, p \leq 0.01$

TABEL 4b: Hiërargiese regressie-ontledings met transendente geestelike welstand as onafhanklike veranderlike en emosionele coping as tussenkomende veranderlike. Stappe

\begin{tabular}{lccc}
\hline Stappe & \multicolumn{3}{c}{ Beta } \\
\cline { 2 - 4 } & Transendent (GT) & $\begin{array}{c}\text { Coping } \\
\text { (Emosioneel) }\end{array}$ & GT x Emosioneel \\
\hline 1 & $-0.325^{*}$ & - & - \\
Alternatief 1 & - & -0.066 & - \\
2 & $-0.322^{*}$ & -0.013 & - \\
3 & - & - & -0.109 \\
\hline GT, Geestelike welstand - Transendent. & & \\
$*, p \leq 0.05$ & & &
\end{tabular}

TABEL 4c: Hiërargiese regressie-ontledings met transendente geestelike welstand as onafhanklike veranderlike en disfunksionele coping as tussenkomende veranderlike. \begin{tabular}{lccc}
\hline Stappe & \multicolumn{3}{c}{ Beta } \\
\cline { 2 - 4 } & Transendent (GT) & $\begin{array}{c}\text { Coping } \\
\text { (Disfunksioneel) }\end{array}$ & GT x Disfunksioneel \\
\hline
\end{tabular}

\begin{tabular}{lccc}
\hline 1 & $-0.325^{*}$ & - & - \\
Alternatief 1 & - & $0.382^{* *}$ & - \\
2 & $-0.322^{*}$ & $0.309^{*}$ & - \\
3 & - & - & 0.059 \\
\hline GT, Geestelike welstand & Transendent. & & \\
$*, p \leq 0.05 ; * *, p \leq 0.01$ & & &
\end{tabular}


is, hoe hoër die vlakke van depressie wat hulle ervaar. In ooreenstemming met die literatuur is daar 'n positiewe verband tussen onbetrokke coping-strategieë wat deel vorm van die kategorie disfunksionele coping en simptome van depressie gevind (Jordaan et al. 2007:838) en voorspel onbetrokke coping swakker psigologiese uitkomste (ConnorSmith \& Flachsbart 2007:1081; Pienaar \& Rothmann 2003:81; Van Berkel 2009:4).

Aangesien verbande tussen geestelike welstand en depressie wel gerapporteer word (Sorajjakool et al. 2008:521; Westgate 1996:28-32) en coping met die regulering van emosies (Folkman \& Moskowitz 2004:747; Lazarus 2006:17) en met sekere uitkomste van welstand geassosieer word (ConnorSmith \& Flachsbart 2007:1081; Fortes-Ferreira et al. 2006:293; Van Berkel 2009:3), is daar gevind dat coping 'n belangrike veranderlike in die verband tussen geestelike welstand en depressie mag wees.

Disfunksionele coping word hoofsaaklik gekarakteriseer deur vermydende gedrag (Carver et al., 1989:269), terwyl persoonlike geestelike welstand na 'n groter mate van selfbewussyn, selfwaarde en identiteit verwys (Fisher 1998:14, 121; Fisher et al. 2000:135; Gomez \& Fisher 2003:1976; Gomez \& Fisher 2005:1110). 'n Negatiewe kognitiewe patroon teenoor die self, toekoms en ervaringe kan aanleiding gee tot simptome van depressie (Beck 2002:31; Clark et al. 1999:51). Uit die resultate van die studie is disfunksionele coping as 'n mediator in die verband tussen persoonlike geestelike welstand en depressie by predikante geïdentifiseer. Dit beteken dat hoër vlakke van persoonlike geestelike welstand by predikante lei tot laer vlakke van disfunksionele coping en gevolglik tot ' $n$ afname in depressie.

Emosionele coping is as moderator in die verband tussen omgewingsverwante geestelike welstand en depressie by die ondersoekgroep geïdentifiseer. Dit dui daarop dat predikante met hoë vlakke van emosionele coping 'n redelik vinnige afname in depressie ervaar sodra daar 'n toename in omgewingsverwante geestelike welstand by hulle aanwesig is, terwyl by predikante met lae vlakke van emosionele coping die afname in depressie, met die toename in omgewingsverwante geestelike welstand, nie so vinnig en groot in omvang is nie. Die literatuur dui daarop dat predikante geneig is om van sosiale ondersteuning gebruik te maak en in moeilike omstandighede by geestelike aktiwiteite betrokke raak (Buys \& Rothmann 2009:2; Evers \& Tomic 2003:337; Meek et al. 2003:342-343; Redelinghuys \& Rothmann 2005:466). Beide strategieë vorm deel van emosioneelgebaseerde coping en omgewingsverwante geestelike welstand. Die strategieë kan dus moontlik vir predikante as suksesvol beskou word binne die kategorie van emosioneelgebaseerde coping om sielkundige spanning te verlaag.

Verdere navorsing ten opsigte van die verband tussen geestelike welstand en depressie moet onderneem word, tesame met die bestudering van bykomende veranderlikes, soos persoonlikheidstipes, emosionele intelligensie, nagraadse teologiese studie en finansiële stabiliteit, wat moontlik'n rol in hierdie verband kan speel. Die predikantekorps verdien meer aandag in die Suid-Afrikaanse konteks, en meer diepgaande navorsing oor faktore wat ' $n$ invloed kan uitoefen op hulle welstand, word benodig. Aangesien die ondersoekgroep 'n gerieflikheidssteekproef was en slegs verteenwoordigend is van die Noord-Kaapse predikantekorps, kan die resultate van die studie nie na die groter predikantepopulasie veralgemeen word nie. Verdere navorsing rakende die onderwerp kan in die toekoms onderneem word met die insluiting van individue uit ' $n$ verskeidenheid denominasies en kultuurgroepe.

\section{Erkennings \\ Mededingende belange}

Die outeurs verklaar dat hulle geen finansiële of persoonlike verbintenis het met enige party wat hulle nadelig kon beïnvloed in die skryf van hierdie artikel.

\section{Literatuurverwyings}

Anastasi, A. \& Urbania, S., 1997, Psychological testing, Prentice Hall, Upper Saddle River, NJ.

Barlow, D.H. \& Durand, V.M., 2009, Abnormal psychology, 5th edn., Thomson Wadsworth, Victoria, Australia.

Beck, A.T., 1970, Depression: Causes and treatment, University of Pennsylvania Press, Philadelphia, PA.

Beck, A.T., 2002, 'Cognitive models of depression', in R.L. Leahy \& E.T. Dowd (eds.), Clinical advances in cognitive psychotherapy: Theory and application, pp. 29-61, Springer, New York, NY.

Beck, A.T. \& Alford, B.A., 2009, Depression: Causes and treatment, 2nd edn., University of Pennsylvania Press, Philadelphia, PA.

Beck, A.T., Rush, A.J., Shaw, B.F. \& Emery, G., 1979, Cognitive therapy of depression, The Guilford Press, New York, NY.

Beck, A.T., Steer, R.A., Ball, R. \& Ranieri, W.F., 1996, 'Comparison of the Beck Depression Inventories $-1 A$ and -11 in psychiatric outpatients', Journal of Personality Assessment 67(3), 588-597. http://dx.doi.org/10.1207/s15327752jpa6703_13, PMid:8991972

Beck, A.T., Steer, R.A. \& Brown, G.K., 1996, Beck Depression Inventory, Psychological Corporation, San Antonio, TX.

Breytenbach, M.C., 2004, 'Die invloed van gemeentedemografie op die fisieke aktiwiteit- en stressimptoomindeks by N.G. predikante', ongepubliseerde magister verhandeling, Skool van Biokinetika, Rekreasie en Sportwetenskap, NoordwesUniversiteit, Potchefstroom, besigting 18 April 2011 by http://dspace.nwu.ac.za/ bitstream/10394/659/1/breytenbach_mc.pdf

Buys, C. \& Rothmann, S., 2009, 'Job demands and job resources in the ministry', SA Journal of Human Resource Management/SA Tydskrif vir Menslikehulpbronbestuur 7(1), 1-10. http://dx.doi.org/10.4102/sajhrm.v7i1.202

Buys, C. \& Rothmann, S., 2010, 'Burnout and engagement of reformed church ministers', SA Journal of Industrial Psychology/SA Tydskrif vir Bedryfsielkunde 36(1), 1-10. http://dx.doi.org/10.4102/sajhrm.v7i1.202

Carr, A., 2001, Abnormal psychology, Psychology Press, East Sussex.

Carver, C.S., Scheier, M.F. \& Weintraub, J.K., 1989, 'Assessing coping strategies: A theoretically based approach', Journal of Personality and Social Psychology 56(2), 267-283. http://dx.doi.org/10.1037/0022-3514.56.2.267, PMid:2926629

Chiu, L., Emblen, J.D., Van Hofwegen, L., Sawatzky, R. \& Meyerhoff, H., 2004, 'An integrative review of the concept of spirituality in the health sciences', Western Journal of Nursing Research 26(4), 405-428. http://dx.doi.org/10.1177/0193945904263411, PMid:15155026

Clark, D.A., Beck, A.T. \& Alford, B.A., 1999, Scientific foundations of cognitive theory and therapy of depression, John Wiley \& Sons, New York, NY.

Connor-Smith, J.K. \& Flachsbart, C., 2007, 'Relations between personality and coping: A meta-analysis', Journal of Personality and Social Psychology 93(6), 1080-1107. http://dx.doi.org/10.1037/0022-3514.93.6.1080, PMid:18072856

Cooke, F.T., 2007, 'Die gebruik van die pastor pastorum in die pastorale versorging van die predikante van die Nederduitse Gereformeerde Kerk', ongepubliseerde doktorale proefskrif, Fakulteit Teologie, Universiteit van Pretoria.

Dubovsky, S.L. \& Dubovsky, A.N., 2002, Concise guide to mood disorders, American Psychiatric Publishing, Washington DC. 
Evers, E. \& Tomic, W., 2003, 'Burnout among Dutch Reformed pastors', Journal of Psychology and Theology 31(4), 329-338.

Fisher, J.W., 1998, 'Spiritual health: Its nature and place in the school curriculum', unpublished Phd thesis, Department of Science and Mathematics Education University of Melbourne, viewed 18 April 2011, from http://dtl.unimelb.edu.au/R/2H TRRNAHGS1XIM7TFYMVTNM17VFJH2F49Y DLFYDC3AGVHVX9D5-00136?func=dbinjump-full\&object_id $=67162 \&$ pds_ handle $=$ GUEST

Fisher, J.W., Francis, L.J. \& Johnson, P., 2000, 'Assessing spiritual health via four domains of spiritual wellbeing: The SH4DI', Pastoral Psychology 49(2), 133-145. http://dx.doi.org/10.1023/A:1004609227002

Folkman, S. \& Moskowitz, J.T., 2004, 'Coping: Pitfalls and promise', Annual Reviews Psychology 55, 745-774. http://dx.doi.org/10.1146/annurev.psych.55.090902. 141456

Fortes-Ferreira, L., Peiró, J.M., González-Morales, G. \& Martín, I., 2006, 'Work-related stress and well-being: The roles of direct action coping and palliative coping' Scandinavian Journal of Psychology 47, 293-302. http://dx.doi.org/10.1111/ j.1467-9450.2006.00519.x, PMid:16869862

Gomez, R. \& Fisher, J.W., 2003, 'Domains of spiritual well-being and development and validation of the Spiritual Well-being Questionnaire', Personality and Individual Differences 35, 1975-1991. http://dx.doi.org/10.1016/S0191-8869(03)00045-X

Gomez, R. \& Fisher, J.W., 2005, 'Item response theory analysis of the Spiritual Wellbeing Questionnaire', Personality and Individual Differences 38, 1107-1121. http://dx.doi.org/10.1016/j.paid.2004.07.009

Gotlib, I.H. \& Hammen, C.L., 2009, 'Introduction', in I.H. Gotlib \& C.L. Hammen (eds.), Handbook of depression, 2nd edn., pp. 1-2, The Guilford Press, New York, NY.

Gravetter, F.J. \& Wallnau, L.B., 2000, Statistics for the behavioural sciences, 5th edn., Wadsworth/Thomson, Belmont, CA.

Grobbelaar, K.G., 2007, 'Hulpverlening tot streshantering by predikante van die Gereformeerde Kerke in Suid-Afrika (GKSA): 'n Pastorale studie', Fakulteit Teologie, ongepubliseerde doktorale proefskrif, Noordwes-Universiteit, besigtig 18 April 2011, by http://dspace.nwu.ac.za/handle/10394/1293

Henriques, G. \& Leitenberg, H., 2002, 'An experimental analysis of the role of cognitive errors in the development of depressed mood following negative social feedback', Cognitive Therapy and Research 26(2), 245-260. http://dx.doi. org/10.1023/A:1014577904837

Herbst, L., Coetzee, S. \& Visser, D., 2007, 'Personality, sense of coherence and the coping of working mothers', SA Journal of Industrial Psychology/SA Tydskrif vir Bedryfsielkunde 33(3), 57-67.

Hodges, H., 2002, 'Mental health, depression, and dimensions of spirituality and religion', Journal of Adult Development 9(2), 109-115.

Howell, D.C., 2007, Fundamental Statistics for the Behavioral Sciences, Wadsworth, Belmont, CA.

Hyman, C. \& Handal, P.J., 2006, 'Definitions and evaluation of religion and spirituality items by religious professionals: A pilot study', Journal of Religion and Health 45(2), 264-282. http://dx.doi.org/10.1007/s10943-006-9075-z

Jordaan, I., Spangenberg, J.J., Watson, M.B. \& Fouché, P., 2007, 'Emotional stress and coping-strategies in South African clinical and counselling psychologists', South African Journal of Psychology 37(4), 835-855.

Lazarus, R.S., 2006, 'Emotions and interpersonal relationships: Toward a person centered conceptualization of emotions and coping', Journal of Personality, 74(1) 9-46. http://dx.doi.org/10.1111/j.1467-6494.2005.00368.x, PMid:16451225
Lazarus, R.S. \& Folkman, S., 1984, Stress, appraisal, and coping, Springer, New York, NY

McGinn, L.K., 2000, 'Cognitive behavioral therapy of depression: Theory, treatment, and empirical status', American Journal of Psychotherapy 54(2), 257-262.

McIntosh, C.N. \& Fischer, D.G., 2000, 'Beck's cognitive triad: One versus three factors', Canadian Journal of Behavioural Science 32(3), 153-157. http://dx.doi. org/10.1037/h0087110

Meek, K.R., McMinn, M.R., Brower, C.M., Burnett, T.D., McRay, B.W., Ramey, M.L. et al., 2003, 'Maintaining personal resiliency: Lessons learned of Evangelical Protestant Clergy', Journal of Psychology and Theology 31(4), 339-347.

Meyer, R., Rothmann, S. \& Pienaar, J., 2003, 'Coping, stress and suicide ideation in the South African Police Service in the Eastern Cape', South African Journal of Economic and Management Sciences 6(4), 881-904, viewed 18 April 2011, from http://www.ianrothmann.com/pub/ecoman_v6_n4_a12.pdf

Moos, R. \& Schaefer, J.A., 1993, 'Coping resources and processes: Current concepts and measures', in L. Goldberg \& S. Breznitz (eds.), Handbook of stress: Theoretical and clinical aspects, pp. 234-253, Free Press, New York, NY.

Nel, M., 2004, 'Publieke pastorale leiers 1: Roeping, werwing, keuring, opleiding, ordening', Verbum et Ecclesia 25(2), 584-618.

Pienaar, J. \& Rothmann, S., 2003, 'Coping strategies in the South African Police Service', SA Journal of Industrial Psychology/SA Tydskrif vir Bedryfsielkunde 29(4), 81-90, viewed 18 April 2011, from http://www.ianrothmann.com/pub/psyc v29 n4 a9.pdf

Rajakumar, S., Jillings, C., Osborne, M. \& Tognazzini, P., 2008, 'Spirituality and depression: The role of spirituality in the process of recovering from depression' Spirituality and Health International 9, 90-101. http://dx.doi.org/10.1002/shi.333

Redelinghuys, F.J. \& Rothmann, S., 2005, 'Koherensiesin, coping, uitbranding en begeestering van predikante', Tydskrif vir Geesteswetenskappe 45(4), 466-477.

Rothmann, S. \& Van Rensburg, P., 2002, 'Psychological strengths, coping and suicide ideation in the South African Police Services in the North West Province', SA
Journal of Industrial Psychology/SA Tydskrif vir Bedryfsielkunde 28(3), 39-49, viewed 18 April 2011, from http://www.ianrothmann.com/pub/psyc_v28_n3 a6.pdf

Sadock, B.J. \& Sadock, V.A., 2007, Synopsis of psychiatry: Behavioral sciences/clinical psychiatry, 10th edn., Lippincott Williams \& Wilkins, Philadelphia, PA.

Serretti, A., 2005, 'Genetics of mood disorders', in E.J.L. Griez, C. Faravelli, D.J. Nutt \& J. Zohar (eds.), Mood disorders: Clinical management and research issues, pp. 35-76, John Wiley \& Sons, West Sussex. http://dx.doi.org/10.1002/0470094281. ch2

Sorajjakool, S., Aja, V., Chilson, B., Ramírez-Johnson, J. \& Earll, A., 2008, 'Disconnection, depression, and spirituality: A study of the role of spirituality and meaning in the lives of individuals with severe depression', Pastoral Psychology 56(5), 521-532. http://dx.doi.org/10.1007/s11089-008-0125-2

SPSS Incorporated, 2009, SPSS user's guide: Version 17.0, SPSS Incorporated New York, NY.

Stevens, L. \& Rodin, I., 2007, Psychiatry: An illustrated colour text, Elsevier, Philadelphia,

Van Berkel, H., 2009, 'The relationship between personality, coping styles and stress, anxiety and depression', unpublished master thesis, University of Canterbury, Christchurch, viewed 18 April 2011, from http://ir.canterbury.ac.nz/ bitstream/10092/2612/1/thesis_fulltextpdf.pdf

Westgate, C.E., 1996, 'Spiritual wellness and depression', Journal of Counseling and Development 75, 26-35. http://dx.doi.org/10.1002/j.1556-6676.1996.tb02311.x 